\title{
Comparative effects of beta adrenergic blocking drugs
}

\author{
E D A R SOWTON, D. S. DAS GUPTA ${ }^{1}$, \\ a n d I. B A K E R
}

The Cardiac Department, Guy's Hospital, London SEI

\begin{abstract}
Sowton, E., Das Gupta, D. S., and Baker, I. (1975). Thorax, 30, 9-18. Comparative effects of beta adrenergic blocking drugs. Although many different beta blockers are now in clinical use, there is very little information concerning their relative efficacy, and it is still not clear what clinical importance should be attached to properties such as positive inotropic stimulation (intrinsic sympathomimetic activity or ISA) and membrane stabilizing action ('local anaesthetic effect' or 'quinidine-like effect'). In this report we compare the ability of patients with angina to exercise on a bicycle ergometer while receiving a series of commonly used beta blockers, and attempt to determine the importance of ISA. The investigation is in four parts with the drugs given orally or intravenously: statistical analysis of the results was carried out using standard methods, both parametric and non-parametric (Friedmann analysis of variance, Wilcoxon matched pairs signed ranks test) by two independent statisticians.

The relevant properties of drugs included in this paper are summarized in Table $I$. Laboratory reports using many different animal preparations may differ from this assessment under specific conditions, and the Table is intended only as a guide to the generally accepted properties of these drugs when used clinically. Results for sotalol are included for reference in the first part of this paper but the drug was withdrawn from clinical use and was not studied further.
\end{abstract}

T A B L E I

\begin{tabular}{|c|c|c|c|c|}
\hline Drug & Trade Name & Route given & $\begin{array}{c}\text { Membrane } \\
\text { Activity }\end{array}$ & ISA \\
\hline $\begin{array}{l}\text { Propranolol } \\
\text { Practolol } \\
\text { Alprenolol } \\
\text { Oxprenolol } \\
\text { MJ 1999 } \\
\text { Pindolol (LB46) }\end{array}$ & $\begin{array}{l}\text { Inderal } \\
\text { Eraldin } \\
\text { Aptin } \\
\text { Trasicor } \\
\text { Sotalol } \\
\text { Visken }\end{array}$ & $\begin{array}{l}\text { IV and oral } \\
\text { IV and oral } \\
\text { IV and oral } \\
\text { IV and oral } \\
\text { IV } \\
\text { Oral }\end{array}$ & $\begin{array}{l}\text { Yes } \\
\text { Minimal } \\
\text { Yes } \\
\text { Yes } \\
\text { Minimal } \\
\text { Minimal }\end{array}$ & $\begin{array}{l}\text { No } \\
\text { Yes } \\
\text { Yes } \\
\text { Yes } \\
\text { No } \\
\text { Yes }\end{array}$ \\
\hline
\end{tabular}

\section{HAEMODYNAMIC COMPARISONS OF DRUGS}

As a basis for subsequent assessment of doses and consideration of importance of ISA we present here some haemodynamic results obtained by Hoy, Gibson, and Sowton which have previously been unpublished. Measurements of cardiac output (dye dilution technique), intra-arterial pressure (via $1 \mathrm{~mm}$ Teflon tubes introduced percutaneously into the brachial artery), and heart rate (from ECG recordings) were taken during

'Present address: Department of Cardiology, University of Chicago Hospitals, 950 East 59th Street, Chicago, Illinois 60637, USA steady-state erect exercise at $300 \mathrm{kpm} /$ minute on a bicycle ergometer. Control measurements were made 6 minutes after the start of the exercise, and drug-induced changes were measured a further 6 minutes following intravenous injection of one of five beta-blocking drugs. The haemodynamic results are shown in Fig. 1, illustrating that there are considerable differences between these drugs, particularly with regard to practolol; it might be anticipated that these differences are reflected in the clinical responses of patients with angina.

\section{COMPARISON OF DIFFERENT INTRAVENOUS DOSES} AT SEVERAL EXERCISE LEVELS

Further data were obtained by comparing the inhibition of exercise tachycardia by four beta blocking drugs in groups of normal volunteers and patients. The results are the mean from six subjects, and between groups there were no significant differences of heart rate at rest or at each 


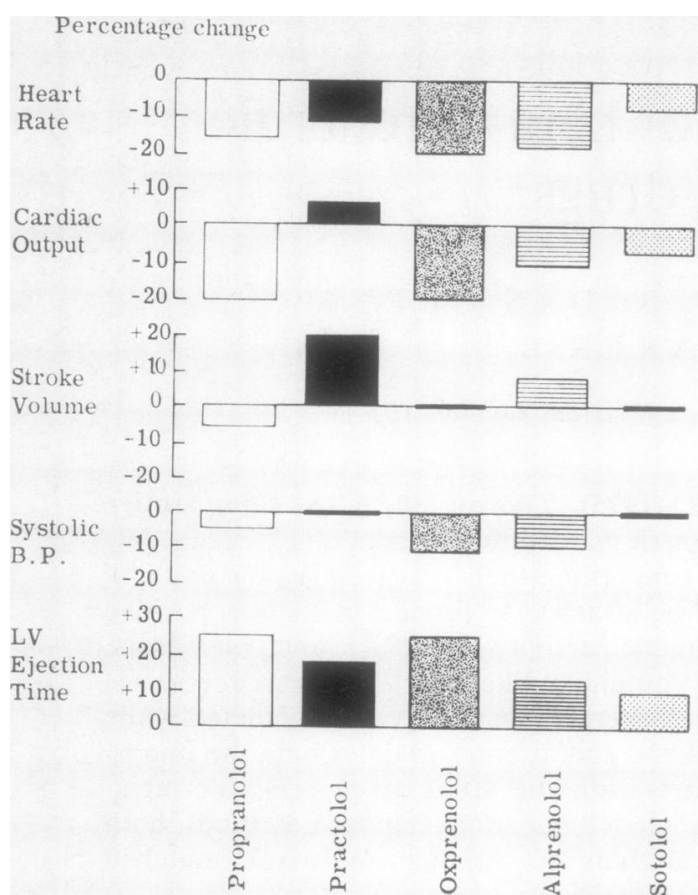

FIG. 1. Haemodynamic changes 6 minutes after $5 \mathrm{mg}$ intravenous $\beta$ blocker during erect exercise.

exercise level on placebo tests. Also, there were no significant differences in mean age nor in the total amount of exercise performed after either placebo or active drugs. Preliminary results with two drugs have been presented elsewhere (Sowton, 1970). Each subject underwent an exercise test, in which the maximal work load was established, and on each of four subsequent days re-exercised at levels of one quarter, one half, three quarters, and maximum tolerance. A warm-up period of exercise, followed by 20 minutes' rest, preceded the definitive test on each occasion. At rest and for two minutes at each exercise level the heart rate was measured following intravenous injection of placebo (saline) and $0.5 \mathrm{mg}, 1.5 \mathrm{mg}$ and $5 \mathrm{mg}$ of active drug. Each investigation therefore consisted of five exercise tests, during the last three of which the subject had cumulative doses of $0.5 \mathrm{mg}, 1.5 \mathrm{mg}$, and $5 \mathrm{mg}$ of the test drug. Fig. 2 shows representative results following saline, propranolol, practolol, and alprenolol injections.

The reduction in heart rate with propranolol was taken as $100 \%$ and the changes following other drugs were expressed proportionately. There were only minor differences in results for normal subjects or patients, and so these groups have been combined. The results are summarized Table II.

There is a tendency for these drugs to approact more closely the effect of propranolol as the exer cise level was increased, and also (with the excep? tion of sotalol) as the dose level was increased. के

The molecular weights of the drugs are similar $\overrightarrow{0}$ and so this milligram for milligram comparisonapproximates to a molecule for molecule basis $\vec{\omega}$ The relative potencies of the drugs differ con $=$ siderably and it is noteworthy that they differ from values established in antagonism of aro isoprenaline-induced tachycardia in laboratory animals (cats) as determined by Barrett an Carter (1970) and shown in Table III.

T A B L E I I

COMPARATIVE SLOWING OF TACHYCARDIA DURING ERECT EXERCISE (Propranolol effect $=100 \%$

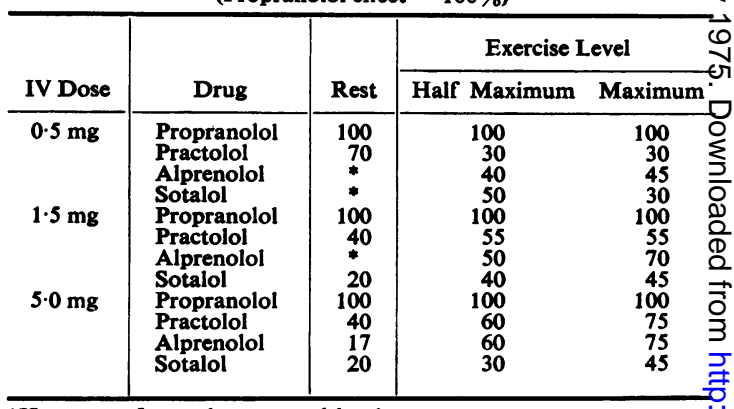

*Heart rate faster than control level.

T A B L E I I I

ANTAGONISM OF ISOPRENALINE TACHYCARDIA IN CATS

\begin{tabular}{|c|c|}
\hline Drug & $\begin{array}{l}\text { Relative } \\
\text { Potencies }\end{array}$ \\
\hline $\begin{array}{l}\text { Propranolol } \\
\text { Alprenolol } \\
\text { Oxprenolol } \\
\text { Practolol } \\
\text { Sotalol } \\
\text { Pindolol }\end{array}$ & $\begin{array}{r}100 \\
103 \\
187 \\
40 \\
8 \\
2,480\end{array}$ \\
\hline
\end{tabular}

COMPARATIVE INTRAVENOUS TRIAL IN ANGINA

The relative effects on exercise tolerance in 120 patients with angina pectoris were studied using intravenous injections of four beta blocking drugso in doses based upon the results given above and aD consideration of the literature. These doses were: + ? propranolol $5 \mathrm{mg}$, oxprenolol $5 \mathrm{mg}$, alprenolot $10 \mathrm{mg}$, and practolol $40 \mathrm{mg}$; in each case the manufacturers confirmed that these doses might be expected to produce similar improvement in exercise tolerance. The drug solutions were pre? pared in the Guy's Hospital pharmacy and thes 

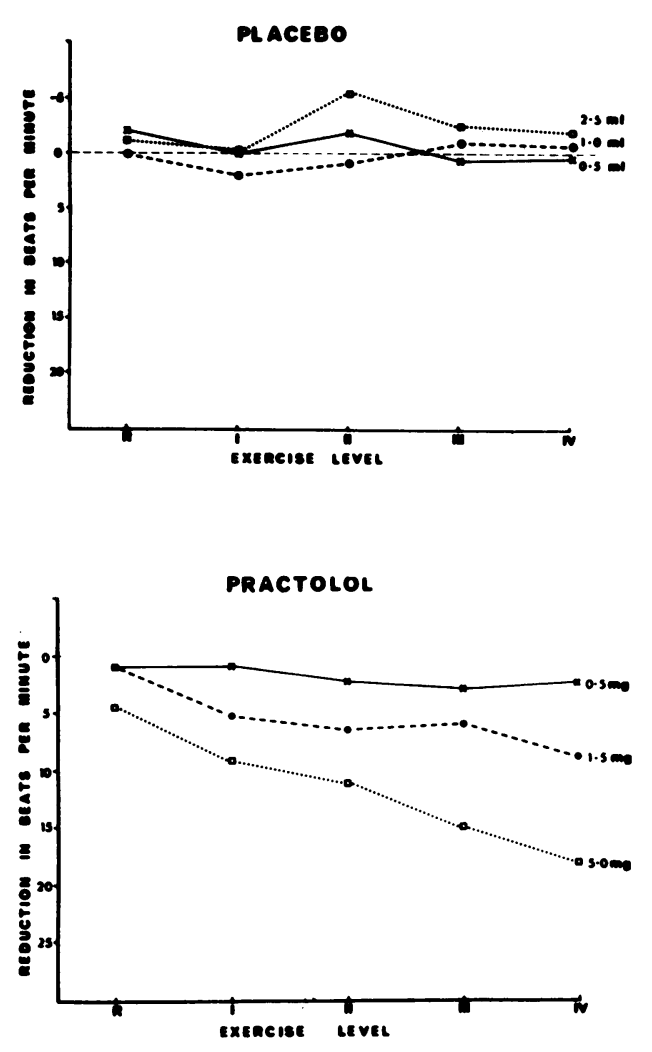
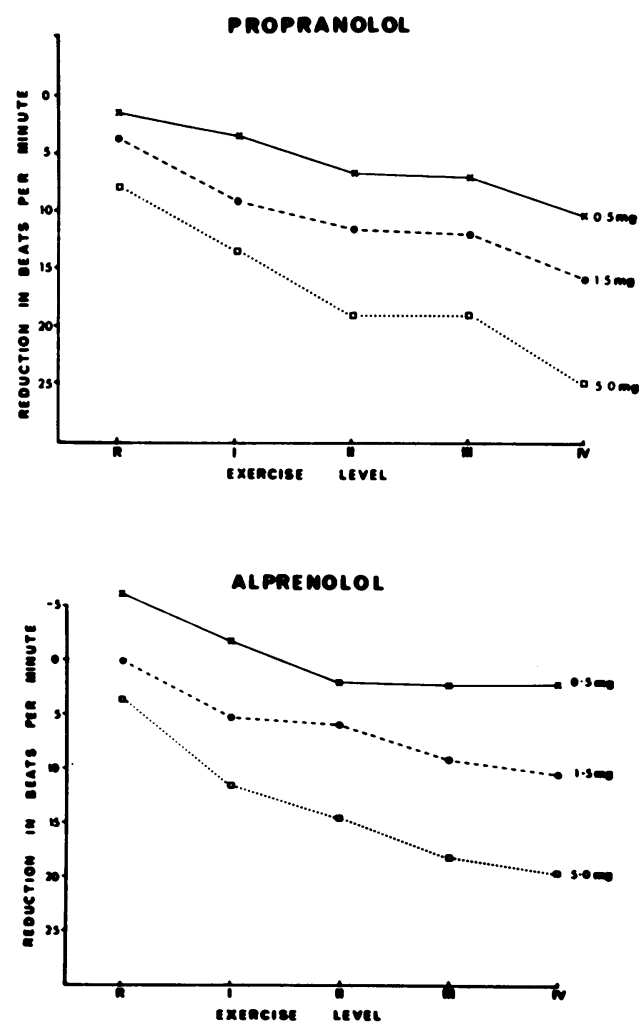

FIG 2.

trial was double-blind; the order of drugs was randomized, and all patients received all drugs. All patients had typical histories of angina pectoris for the last three months and had abnormal ECGs with typical ischaemic ST segment depression during exercise. There were $10 \mathrm{men}$ and two women with a mean age of 51 years; none had hypertension, valve disease, asthma, or chronic bronchitis, or gave a history of heart failure. All had agina graded 2 or 3 (moderate or severe) on a 4-point scale in which grade 4 represents angina occurring at rest (Balcon, Maloy, and Sowton, 1968). The only other drug used was sublingual nitroglycerine, which was not taken on the morning of the investigations.

Exercise testing was carried out according to a standardized protocol at 9 am on separate days in the sitting position on a bicycle ergometer (Elema-Schönander). An initial warm-up for 3 minutes at $200 \mathrm{kpm} /$ minute was followed by rest until the heart rate had returned to control values (typically 20 to 30 minutes). An intravenous injection of $20 \mathrm{ml}$ normal saline was given and exercise was begun 3 minutes later at a work load of $200 \mathrm{kpm} / \mathrm{minute}$. The work load was increased by $200 \mathrm{kpm} /$ minute every 3 minutes until anginal pain was produced; ECGs were continuously monitored. Recordings were taken for 15 seconds before the one-minute point and threeminute point at each work load, as well as at the onset of anginal pain. The patients were then allowed to rest again until heart rates had returned to baseline values, and $20 \mathrm{ml}$ of beta-blocking solution was injected. The exercise test was then repeated using the same protocol. Assessment of exercise tolerance was made by calculating the total work performed before the onset of angina, and the improvement over saline values was taken as a measure of the drug effect. There were no complications during this investigation and no patient complained of side effects.

RESULTS The mean increase in total work before pain was greatest with practolol $(1,250 \mathrm{kpm})$ followed by alprenolol $(1,050 \mathrm{kpm})$ and oxprenolol $(575 \mathrm{kpm})$ with propranolol, the only drug 
without ISA, the lowest $(340 \mathrm{kpm})$. However, the difference between propranolol and practolol results has a $P$ value of only $0 \cdot 10$. Table IV shows increase in work for each drug, together with a ranking order in which 1 represents the best drug and 4 the worst.

T A B L E I V

INCREASE IN WORK KILOPONDMETERS (DRUG - SALINE)

\begin{tabular}{|c|c|c|c|c|}
\hline Patient & Propranolol & Practolol & Oxprenolol & Alprenolol \\
\hline $\begin{array}{r}1 \\
2 \\
3 \\
4 \\
5 \\
6 \\
7 \\
8 \\
9 \\
10 \\
11 \\
12\end{array}$ & $\begin{array}{r}950 \\
+\quad 500 \\
+\quad 100 \\
+\quad 250 \\
+\quad 125 \\
+\quad 900 \\
+\quad 550 \\
+\quad 800 \\
+\quad 200 \\
0 \\
+1,200\end{array}$ & $\begin{array}{r}+3,400 \\
+3,300 \\
+\quad 400 \\
+\quad 500 \\
+\quad 450 \\
+1,250 \\
+300 \\
+3,650 \\
+\quad 900 \\
0 \\
+\quad 800 \\
+1,700\end{array}$ & $\begin{array}{l}600 \\
+1,300 \\
+\quad 500 \\
+\quad 150 \\
+\quad 900 \\
+1,050 \\
+\quad 300 \\
+1,900 \\
+\quad 800 \\
+450 \\
+1,400 \\
+\quad 900\end{array}$ & $\begin{array}{r}+1,700 \\
+1,300 \\
+\quad 300 \\
+\quad 900 \\
+1,400 \\
+1,650 \\
+1,500 \\
+800 \\
+\quad 850 \\
+1,600 \\
+1,200\end{array}$ \\
\hline $\begin{array}{c}\text { Mean } \\
\text { Ranking } \\
\text { order }\end{array}$ & $\begin{array}{c}327 \\
4\end{array}$ & $\begin{array}{c}+1,263 \\
1\end{array}$ & $\begin{array}{c}554 \\
3\end{array}$ & $\begin{array}{c}+1,025 \\
2\end{array}$ \\
\hline
\end{tabular}

A non-parametric analysis of variance shows that alprenolol and practolol are indistinguishable and that both are better than propranolol $(P<0 \cdot 10)$ with oxprenolol intermediate and not significantly different.

It is possible that a training effect occurred during the trial. If the mean values for increase in work on each day are taken irrespective of the drug given, the values in Table $\mathrm{V}$ are obtained.

T A B L E V

MEAN VALUES FOR INCREASE IN WORK $(\mathrm{kpm})$

\begin{tabular}{c|cccc}
\hline & 1st Day & 2nd Day & 3rd Day & 4th Day \\
\cline { 2 - 5 } $\begin{array}{c}\text { Saline } \\
\text { Drug }\end{array}$ & $\mathbf{1 , 7 0 0}$ & $\mathbf{2 , 4 3 0}$ & $\mathbf{2 , 1 0 0}$ & $\mathbf{2 , 0 4 0}$ \\
\hline
\end{tabular}

Values for the first day are significantly $(P<0.05)$ lower than those for the second day, both for saline and for active drug. There is no significant difference between the second and third days, nor between the third and fourth. It is impossible for all combinations of order of administration to be achieved with the number of patients available, and the randomization resulted in seven of the 12 propranolol tests occurring on the fourth day. It is possible that this unfavourably influenced the propranolol results, but even when this factor is considered, together with the likelihood that the doses chosen were not equivalent for all patients, the differences we found were only at the $10 \%$ level.
COMPARATIVE ORAL TRIAL IN ANGINA

The purpose of this portion of the investigation was to determine whether the differing haemo dynamic properties discussed earlier, in particular the presence of ISA, had clinical importance in the treatment of angina, and also to assess if the responses to intravenous doses correlated with $\overrightarrow{0}$ those following oral administration. A double $=$ blind crossover trial was carried out in 20 patients with typical histories of angina who were already stabilized on propranolol as a clinical treatment In view of reports that replacement of oxprenolol, $\mathrm{O}$ practolol or propranolol with placebo may result in a severe exacerbation of angina (Turner and Peel, 1970), we felt it unethical to include a placebo in this particular group and so the triat was carried out using five beta blockers only묭 Criteria for exclusion were similar to those for: the intravenous trial, with the addition of gastrointestinal disturbances; seven of the patients com $\overrightarrow{0}$ pleting the intravenous trial also took part in the oral trial and their results are compared later as a separate group.

After a run-in period on beta blockers of at least six weeks, including an exercise test as pre-o viously described, the patients had another stan $\frac{\pi}{\varnothing}$ dard exercise test at entry to the trial proper. Clinical examination, 12-lead ECG, laboratory $\overrightarrow{\overrightarrow{0}}$ tests for serum enzymes, blood urea, haemoglobin,? blood film ESR, and electrolytes, together with further exercise tests including a warm-up, were. then carried out every two weeks over a 10 -week period. At each visit patients were questioned about side effects, and a nitroglycerine test, as ${ }^{x}$ described by Fitzgerald (1970), was carried out tos confirm beta blockade.

The drugs used, and the equivalent doses chosen after consultation with the manufacturers, are shown in Table VI.

T A B LE V I

'EQUIVALENT DOSES' GIVEN ORALLY IN ANGINA

\begin{tabular}{|c|c|c|}
\hline Drug & Manufacturer & 'Equivalent Dose' \\
\hline 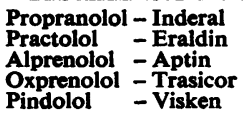 & $\begin{array}{l}\text { ICI } \\
\text { ICI } \\
\text { Astra } \\
\text { Ciba } \\
\text { Sandoz }\end{array}$ & $\begin{array}{r}40 \mathrm{mg} \\
125 \mathrm{mg} \\
100 \mathrm{mg} \\
40 \mathrm{mg} \\
5 \mathrm{mg}\end{array}$ \\
\hline
\end{tabular}

These doses of each compound were preparedo by the Guy's Hospital pharmacy department in? identical gelatine capsules which were subse- $?$ quently administered to the patients for periods $\vec{Q}$ of two weeks each according to a random scheduleo on a double-blind basis. Differences in dose re 
quired by individual patients were allowed for by substituting one capsule for each $40 \mathrm{mg}$ tablet of propranolol previously being taken; the times of administration were unaltered (three or four times daily). Since the patients had been stabilized on a satisfactory clinical dose of propranolol, this technique provided some degree of individual 'dose titration'. The total work performed before angina at the fortnightly exercise test was used as an index of the efficacy of the drug taken over the previous two weeks.

Absorption of active compound from the capsules was checked in three ways. Samples were supplied to the four manufacturers, of whom three (ICI, Sandoz, and Astra) confirmed satisfactory blood levels when the capsules were taken orally. Further capsules were investigated in the clinical pharmacology department of St. Bartholomew's Hospital, London, where adequate blood levels of propranolol, practolol, and pindolol were confirmed. Also, blood samples were repeatedly obtained from patients during the trial and sent to St. Bartholomew's Hospital. The drug present was there identified from a copy of the randomization table, and a knowledge of the patient's number in the trial and the visit at which blood was taken. Samples were analysed for propranolol, practolol or pindolol levels at the hospital, or were forwarded to the laboratories of Astra Limited, Gothenburg, for analysis of alprenolol levels. We were unable to obtain measurements of oxprenolol blood levels or to confirm satisfactory absorption of the compound from our capsules but the heart rates of patients taking these capsules, and the results of nitroglycerine tests (see later, Table IX), together with confirmation that the other four drugs were well absorbed from identical capsules, strongly suggest that oxprenolol was also well absorbed.
RESULTS Full data are available on 17 patients, and mean values are shown in Table VII.

Statistical analysis by both parametric and nonparametric methods shows that there was no significant difference between the exercise performances on propranolol, practolol, alprenolol, and oxprenolol but the group performed less exercise while taking pindolol $(\mathrm{P}<0.05)$. The basal heart rate was lowest on propranolol and highest on pindolol, but these differences are not significant at the $5 \%$ level. The maximum heart rates achieved were also very similar, with the exception of the pindolol results where the level is significantly lower. This result is not due to a lower level of beta blockade because all five drugs produced similar heart rates at similar points during the exercise test. This is detailed in column 6 of Table VII, where the heart rates after 5 minutes' exercise (at which time all patients were performing at $400 \mathrm{kpm} /$ minute and had completed $1,200 \mathrm{kpm}$ of total work) do not differ significantly between drugs. There is a positive correlation between basal heart rate at rest on the ergometer, and the maximal heart rate $(P<0.05)$, for all drugs except oxprenolol $(P<0 \cdot 10)$.

Ranking analysis of the individual results for total work done gives the findings shown in Table VIII.

Nitroglycerine test This test was carried out at each visit, as described by Fitzgerald (1970), after the patient had rested following exercise. The heart rates were essentially the same as preexercise control values before the nitroglycerine was given. The test depends upon the finding that the usual tachycardia produced at rest by sublingual nitroglycerine is largely prevented by pretreatment with beta-blocking drugs. The expected increase of heart rate in an untreated patient is in the order of $25-30$ beats/minute and the mean

T A B L E V I I

COMPARATIVE RESULTS WITH ORAL ADMINISTRATION

\begin{tabular}{|c|c|c|c|c|c|}
\hline Drug & $\begin{array}{c}\text { Total Work } \\
(\mathbf{k p m})\end{array}$ & At Rest & Maximal & Change & $\begin{array}{c}\text { Change after } \\
\text { 1,200kpm }=5 \mathrm{~min} \\
\text { Exercise }\end{array}$ \\
\hline $\begin{array}{l}\text { Propranolol } \\
\text { Practolol } \\
\text { Alprenolol } \\
\text { Oxprenolol } \\
\text { Pindolol }\end{array}$ & $\begin{array}{l}2,247 \\
2,355 \\
2,317 \\
2,343 \\
1,888\end{array}$ & $\begin{array}{l}67 \\
70 \\
70 \\
69 \\
73\end{array}$ & $\begin{array}{r}102 \\
101 \\
106 \\
103 \\
98\end{array}$ & $\begin{array}{l}35 \\
31 \\
36 \\
34 \\
25\end{array}$ & $\begin{array}{l}26 \\
22 \\
26 \\
25 \\
22\end{array}$ \\
\hline
\end{tabular}

T A B L E V I I I

RANKING OF ORAL RESULTS $(n=17)$

\begin{tabular}{c|cccccc}
\hline & Propranolol & Practolol & Alprenolol & Oxprenolol & Pindolol \\
\hline No. of times best drug & 4 & 4 & 4.5 & 4.5 & 0 & \\
\hline
\end{tabular}


results for the 17 patients in this study are given in Table IX.

In all cases these results indicate beta blockade and the figures for each of the five drugs in individual patients show that adequate beta blockade was present on every occasion. There is no evidence that the test is linear, and so no comparisons can be made between the figures with different drugs. We interpret the results as indicating only that the patients were actually taking the capsules, that absorption of the active drug was occurring, and that satisfactory beta blockade was consistently achieved.

Serum drug levels Although we attempted to obtain blood levels for all patients at every visit, technical and transport difficulties rendered some tests invalid; as previously mentioned, no values could be measured for oxprenolol. Satisfactory results were achieved with the other four drugs on a total of 49 occasions; the limits and mean values for each drug are shown in Table $X$ and again indicate good absorption of active compound.

\section{COMPARISON OF INTRAVENOUS AND ORAL ADMINISTRATION}

Full data are available on seven patients who completed both studies. The heart rates are shown in Table XI which illustrates the consistency of results over four separate days for the measure- $\stackrel{\overline{\bar{S}}}{\rightarrow}$ ments. For example, the group means for intravenous saline studies differ by only about $2.5 \%$ at rest and by $4 \%$ at maximum effort.

The total work performed during these two $\stackrel{\circ}{\circ}$ parts of the investigation by each patient is shown in Table XII.

\section{LABORATORY TESTS AND SIDE EFFECTS}

There were no biologically significant changes in $\overrightarrow{\vec{x}}$ haemoglobin, blood films, serum cholesterol or $\dot{\omega}$ blood urea in any patient during this investigation. Serum enzymes varied considerably from visit to $\overrightarrow{0}$ visit but in no case did they exceed the upper 을 limits of normal and no patient developed changes in the resting ECG. Heart failure did not develop, T but this is not surprising since the patients enter- 음 ing the oral trial were already taking propranolol, and subjects liable to develop failure on beta 2 blockers were thus automatically excluded. $\overrightarrow{0}$ Changes in clinical severity of angina, both oे improvement and deterioration, were not great and could not be consistently attributed to change between any of the drugs. The natural variability of symptoms in angina would be expected to result in changes in any group such as ours, and we did not find differences beyond those frequently seen clinically. Comparison of the first and last exercise tests in our oral study, irrespective of the drug taken, confirms that there was no

T A B L E IX

MEAN INCREASE IN RESTING HEART RATES AFTER $0.5 \mathrm{mg}$ SUBLINGUAL NITROGLYCERINE

\begin{tabular}{|c|c|c|c|c|c|}
\hline & Propranolol & Practolol & Alprenolol & Oxprenolol & Pindolol \\
\hline Heart rate & $8 \cdot 2$ & $5 \cdot 1$ & $8 \cdot 6$ & $7 \cdot 8$ & $7 \cdot 9$ \\
\hline
\end{tabular}

T A B L E X

\begin{tabular}{|c|c|c|c|c|c|}
\hline & $\begin{array}{l}\text { Propranolol } \\
\text { (ng/ml) }\end{array}$ & $\begin{array}{c}\text { Practolol } \\
\text { (ug/ml) }\end{array}$ & $\begin{array}{c}\text { Alprenolol } \\
\text { (ng/ml) }\end{array}$ & Oxprenolol & $\begin{array}{l}\text { Pindolol } \\
(\mathrm{ng} / \mathrm{ml})\end{array}$ \\
\hline $\begin{array}{l}\text { Mean blood level } \\
\text { Highest level } \\
\text { Lowest level } \\
\text { No. of readings }\end{array}$ & $\begin{array}{c}70 \cdot 6 \\
177 \cdot 3 \\
18 \cdot 2 \\
13\end{array}$ & $\begin{array}{c}2 \cdot 7 \\
14 \\
12^{1} \cdot 2\end{array}$ & $\begin{array}{r}20 \cdot 2 \\
475 \cdot 2 \\
7 \cdot 4 \\
12\end{array}$ & $\frac{-}{0}$ & $\begin{array}{c}16 \cdot 3 \\
34 \cdot 6 \\
1 \cdot 2 \\
12\end{array}$ \\
\hline
\end{tabular}

T A B L E X I

MEAN HEART RATES DURING ORAL AND IV ADMINISTRATION (n $=$ (7)

\begin{tabular}{|c|c|c|c|c|}
\hline Heart Rate & Propranolol & Practolol & Alprenolol & Oxprenolol \\
\hline $\begin{array}{l}\text { At rest after IV saline } \\
\text { At maximum effort after IV saline } \\
\text { At rest after IV drug } \\
\text { At maximum effort after IV drug } \\
\text { At rest after oral drug } \\
\text { At maximum effort after oral drug }\end{array}$ & $\begin{array}{r}81 \cdot 4 \\
115 \cdot 6 \\
72 \cdot 9 \\
107.9 \\
64 \cdot 0 \\
100\end{array}$ & $\begin{array}{r}81 \cdot 7 \\
118 \cdot 7 \\
72 \cdot 7 \\
102 \cdot 3 \\
68 \cdot 0 \\
101\end{array}$ & $\begin{array}{l}83 \cdot 4 \\
120 \\
79 \cdot 3 \\
105 \\
69 \cdot 0 \\
106\end{array}$ & $\begin{array}{r}82 \cdot 4 \\
114 \cdot 1 \\
73 \cdot 9 \\
102 \cdot 7 \\
65 \cdot 0 \\
102\end{array}$ \\
\hline
\end{tabular}


T A B L E X I I

TOTAL WORK (kpm) AFTER IV AND ORAL ADMINISTRATION

\begin{tabular}{|c|c|c|c|c|c|c|c|c|}
\hline \multirow[t]{2}{*}{ Patient } & \multicolumn{2}{|c|}{ Propranolol } & \multicolumn{2}{|c|}{ Practolol } & \multicolumn{2}{|c|}{ Alprenolol } & \multicolumn{2}{|c|}{ Oxprenolol } \\
\hline & IV & Oral & IV & Oral & IV & Oral & IV & Oral \\
\hline $\begin{array}{l}1 \\
2 \\
3 \\
4 \\
5 \\
6 \\
7\end{array}$ & $\begin{array}{l}3,500 \\
4,300 \\
1,100 \\
1,250 \\
3,000 \\
1,700 \\
2,100\end{array}$ & $\begin{array}{r}1,200 \\
1,200 \\
3,300 \\
3,150 \\
600 \\
2,700 \\
3,450\end{array}$ & $\begin{array}{l}4,500 \\
6,000 \\
1,400 \\
1,500 \\
1,950 \\
1,950 \\
1,800\end{array}$ & $\begin{array}{l}1,400 \\
2,250 \\
3,450 \\
3,400 \\
2,400 \\
2,400 \\
3,200\end{array}$ & $\begin{array}{l}4,400 \\
3,500 \\
1,300 \\
1,300 \\
2,100 \\
3,000 \\
3,500\end{array}$ & $\begin{array}{l}1,400 \\
1,400 \\
2,550 \\
3,500 \\
3,000 \\
1,800 \\
3,000\end{array}$ & $\begin{array}{r}800 \\
4,400 \\
1,100 \\
550 \\
2,000 \\
2,250 \\
2,700\end{array}$ & $\begin{array}{l}1,600 \\
1,130 \\
2,550 \\
3,300 \\
3,300 \\
3,400 \\
4,000\end{array}$ \\
\hline Mean & 2,420 & 2,230 & 2,730 & 2,640 & 2,730 & 2,400 & 1,970 & 2,610 \\
\hline Significance & \multicolumn{2}{|c|}{ NS } & \multicolumn{2}{|c|}{ NS } & \multicolumn{2}{|c|}{ NS } & \multicolumn{2}{|c|}{$P<0.05$} \\
\hline
\end{tabular}

$\mathrm{NS}=$ not statistically significant.

significant change in exercise performance, which suggests that the group as a whole had not deteriorated due to progression of disease during the trial.

Side effects were notably absent also, possibly because of the selection of patients already taking beta blockers. Complaints of gastrointestinal disturbance were made on three occasions, each time with a different drug, and one patient taking propranolol capsules complained of blurred vision. This had not occurred during pre-trial treatment with propranolol, and it disappeared during the following treatment period with a different drug.

\section{DISCUSSION}

The haemodynamic changes produced by beta blockers we report here are in keeping with many other reports in the literature which, however, usually deal with individual drugs. Despite these differences all the drugs resulted in very similar exercise performance after either intravenous or oral administration. Administration of drugs with ISA was associated with higher resting heart rates than during propranolol therapy in each of our studies reported here, and this is in keeping with published findings (Hill and Turner, 1969; Hetherington, Comerford, Nyberg, and Besterman, 1973; Gibson, 1974). In our oral five drug trial, the highest resting rates were found with pindolol, which has the greatest ISA, and the lowest with propranolol, as expected, but the differences were not great and do not reach the $5 \%$ level. During exercise, differences between the drugs were even less apparent and the increase in exercise tolerance following intravenous injection could not be related to ISA, cardioselectivity or presence of membrane-stabilizing effect. After oral administration also, the exercise tolerance did not differ according to the non-adrenergic blocking properties of the drugs. Similar con- clusions concerning practolol and propranolol were reported by Coltart (1971) and concerning practolol and alprenolol by Sowton (1970). In both these reports individual patients who failed to respond to one drug had very similar exercise performance on the second drug. A similar response occurred in the intravenous trial reported here (patient 5, Table IV). The importance of properties apart from adrenergic receptor blockade in determining the depression of cardiac function produced by different drugs has been widely discussed, and it is often held that drugs with ISA cause less depression and so are clinically preferable (Grandjean and Rivier, 1968; Turner and Peel, 1970).

This view is not supported by Gibson (1974) who has extensively reviewed published data and shown that reductions in cardiac output, blood pressure, and heart rate are linearly related for all beta blockers except practolol, and that results with all non-cardioselective drugs so far published can be expressed by a single regression line. Hetherington et al. (1973) found no difference in cardiac depression between oral alprenolol and propranolol in patients with angina; a similar conclusion was reached by Kerber, Goldman, Alderman, and Harrison (1972).

The importance of adjusting the dose of beta blockers for an individual patient has been emphasized, particularly by Gillam and Prichard (1966) for propranolol, and by Sealey, Liljedal, Nyberg, and Ablad (1971) for alprenolol, as well as by many other workers, and our oral comparison trial goes some way towards this. In any crossover double-blind trial it is not possible to adjust doses of the separate drugs independently, and so it is unlikely that our patients were taking optimal doses during each treatment period. Another complicating factor may be that different patients were not at similar points on the dose- 
response curve with the same drug, while the situation may be different again with different drugs, even if the dose-response curves are parallel and the same for different patients. Despite these theoretical difficulties in comparing drugs our patients were taking doses which produced very similar clinical effects in reduction of exercise, tachycardia, and improvement of exercise capacity. In particular, the presence of differing degrees of ISA did not affect the exercise results. This is in keeping with an acute trial reported by Thudani et al. (1973), who found that practolol, oxprenolol, and propranolol given in doses which produced similar reductions in exercise heart rate all had similar anti-anginal effects. Similarly, our present results agree with those of Gibson (1974), who reported no difference between intravenous oxprenolol, practolol, and alprenolol compared with propranolol when judged by the reduction of heart rate from any given resting rate. Our findings also agree with those of Coltart (1972), who was unable to show any significant difference in exercise tolerance of patients with angina during treatment with propranolol, practolol or oxprenolol, given intravenously, orally for three days, or after long-term oral therapy on optimal doses. Agreement between intravenous and oral responses following alprenolol has also been reported (Sealey et al., 1971). It is reasonable to conclude from these intravenous trials that ISA is of little importance, but during oral administration the situation is different. Propranolol given orally is metabolized in part to 4-hydroxy propranolol in the liver, and this substance is itself a beta adrenergic blocker which possesses ISA (Fitzgerald and O'Donnell, 1971). This theoretical difference was not reflected in our results, and others (Turner and Peel, 1970) have reported similar findings from intravenous and oral propranolol. It is difficult to reconcile these authors' findings that oxprenolol and pindolol behave differently when given intraveously or orally with our own results; their own explanation that the difference from propranolol is due to the lack of ISA possessed by propranolol is untenable when account is taken of the ISA possessed by the 4-hydroxy metabolite.

The report by Wilson et al. (1968) that the drop in cardiac output produced by intravenous oxprenolol was not found after one month's oral administration could not be confirmed by Majid et al. (1970); from the same group a similar claim for pindolol (Turner and Peel, 1970) also remains unconfirmed.

The similarity of heart rate responses and exer- cise ability produced by the different drugs in our $\stackrel{\overrightarrow{\vec{D}}}{\overrightarrow{\mathrm{S}}}$ seven patients studied with both intravenous and $\bar{C}$ oral administration (Tables XI and XII) leads us $\frac{\overline{\bar{N}}}{\bar{n}}$ to conclude that ISA possessed by the original drug or by its metabolites has negligible impor- $\stackrel{\AA}{\Omega}$ tance clinically. A similar conclusion was reached by Taylor, Thudani, and Sharma (1972).

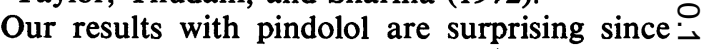
the patients performed significantly less work on $\vec{\omega}$

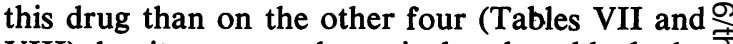
VIII) despite apparently equivalent beta blockade, $\vec{x}$ as shown by virtually identical heart rates after $\omega$ equivalent exercise (Table VII, column 6), by similar results to the nitroglycerine test (Table 0 VIII), and by the satisfactory blood levels of $\frac{}{2}$ pindolol (Table X). The differences cannot be due $\overrightarrow{-}$ to patient selection since all drugs were tested in $\mathbb{T}$ the same patients. The possibility that exercising blood pressures were consistently higher on pindolol than on any of the other beta blockers is extremely unlikely in view of the known hypo- $\vec{\theta}$ tensive actions of pindolol (Doyle et al., 1972; ; Duner, 1972) and the drop in systemic pressure on exercise shown by McCredie (1970). It also seems unlikely that the dose we used was too $\bar{O}$ small since the maximum heart rates achieved on exercise were slower with pindolol than with any $\underset{\Omega}{\mathscr{Q}}$ other drug. It is possible that the dose was in fact $\overrightarrow{\vec{A}}$ too large, and the manufacturers have some evi- $\frac{0}{3}$ dence to suggest that the beneficial effect in angina is reduced at doses above $30 \mathrm{mg}$ per dayo (Maclay, 1974, personal communication). Nine of our 17 patients were taking $30 \mathrm{mg}$ or more of pindolol daily. We have previously reported $\mathrm{a}_{\times}$ reduction of anti-anginal effect when the dose was increased in a group of patients taking alprenolol (Sowton and Smithen, 1971); it is possible that exercise was limited by peripheral effects, but $₹$ elucidation of this finding requires further work. 오

Scrutiny of our individual results suggests that $\supset$ some patients consistently performed better on one of the oral preparations, although this effect $\bar{N}$ was not confined to any one of the drugs. It is. possible that this represents incorrect comparative $\tilde{O}$ dosage for particular patients. If the data we $\mathrm{N}_{\mathcal{N}}$ obtained during intravenous administrationo applies also to the oral route, comparative doseso might vary from patient to patient according to the relative levels of exercise achieved, and might $\stackrel{\odot}{+}$ also vary in a single patient from time to time. 7 The data with oral administration of alprenololo and propranolol reported by Hetherington et al. $\stackrel{\odot}{\oplus}$ (1973) are very similar to our intravenous findings, $\stackrel{\mathbb{Q}}{\circ}$ suggesting a similar pattern of change in comparative doses. 
An alternative explanation, which we consider less likely, is that some patients respond better to a specific drug; this point cannot be decided without individual dose-response curves, which are beyond the scope of the present investigation. It is well recognized that exercise tolerance in patients with angina can vary from day to day; this factor doubtless played a part in our findings and may even be sufficient to explain chance improvements with particular drugs on several occasions.

The clinical implication is that a patient whose angina fails to respond to a beta blocker should initially be treated with an increased dose, but that a different drug should be substituted if there is still no increase in exercise capacity. Our interpretation of these results is that improvement on a second or third beta blocker is unlikely when the first drug has failed. We see no indication to change beta blockers when a patient has responded well to the initial drug, except possibly when side effects such as asthma or gastrointestinal disturbances are troublesome. As our results indicate little clinical difference between the drugs at these doses, the therapeutic choice can be made on the basis of side effects for individual patients.

\section{CONCLUSIONS}

In our patients we have shown:

1. good correlation between the effects of intravenous and oral administration of these beta blocking drugs in patients with angina pectoris;

2. that the possession of intrinsic sympathomimetic activity was of no clinical importance;

3. that haemodynamic differences on mild exercise between different beta blocking drugs were not reflected in ability to improve exercise performance; and

4. that at the doses we used, there was no significant difference on exercise testing between propranolol, practolol, oxprenolol, and alprenolol given to angina patients intravenously or orally.

This work was not sponsored by any pharmaceutical company but we are very grateful to Dr. D. Fitzgerald of ICI, Dr. G. Nyberg and Dr. B. Comerford of Astra, Dr. D. M. Burley of Ciba, and Dr. W. R. Maclay of Sandoz for supplies of drugs and for advice. We are indebted to Dr. Lars Palmer and to Dr. M. Hills for statistical analysis of the results.

We wish particularly to express our thanks to the pharmacy staff at Guy's Hospital for their enthusiastic cooperation and to Professor Paul Turner, Director of the Clinical Pharmacology Department at St. Bartholomew's Hospital, London, for arranging estimation of serum drug levels.

Dr. Das Gupta was in receipt of a grant from the Guy's Hospital Endowment Fund.

\section{REFERENCES}

Balcon, R., Maloy, W. C., and Sowton, E. (1968). Clinical use of atrial pacing test in angina pectoris. British Medical Journal. 3, 91.

Barrett, A. M. and Carter, J. (1970). Comparative chronotropic activity of $\beta$-adrenoceptive antagonists. British Journal of Pharmacology, 40, 373.

Coltart, D. J. (1971). Comparison of effects of propranolol and practolol on exercise tolerance in angina pectoris. British Heart Journal, 33, 62.

(1972). Observations on exercise tolerance in anginal patients treated with beta blockers. New Perspectives in Beta Blockade, p. 167. Proceedings of a Symposium, Aarhus, Denmark, 1972.

Doyle, A. E., Morgan, T. O., Louis, W. J., Dawborn, J. K., and Anavekar S. (1972). The hypotensive action of LB46. Indian Heart Journal, 24, Supplement 1, p. 231.

Duner, H. (1972). The effect of LB46 on the blood pressure in essential hypertension. Indian Heart Journal, 24, Supplement 1, p. 236.

Fitzgerald, J. D. (1970). A new test of the degree of adrenergic beta receptor blockade. International Journal of Clinical Pharmacology, Therapy and Toxicology, 4, 125.

and O' Donnell, S. R. (1971). Pharmacology of 4-hydroxypropranolol, a metabolite of propranolol. British Journal of Pharmacology, 43, 222.

Gibson, D. G. (1974). Pharmacodynamic properties of beta adrenergic receptor blocking drugs in man. Drugs, 7, 8.

Gillam, P. M. S. and Prichard, B. N. C. (1966). Propranolol in the therapy of angina pectoris. American Journal of Cardiology, 18, 366.

Grandjean, T. and Rivier, J. L. (1968). Cardiocirculatory effects of beta-adrenergic blockade in organic heart disease. Comparison between propranolol and Ciba 39, 089Ba. British Heart Journal, 30, 50.

Hetherington, D. J., Comerford, M. B., Nyberg, G., and Besterman, E. M. M. (1973). Comparison of two adrenergic beta-receptor blocking agents, alprenolol and propranolol, in treatment of angina pectoris. British Heart Journal, 35, 320.

Hill, R. C. and Turner, P. (1969). Preliminary investigations of a new beta-adrenoceptive receptor blocking drug, LB46, in man. British Journal of Pharmacology, 36, 368.

Kerber, R. E., Goldman, R. H., Alderman, E. L., and Harrison, D. C. (1972). Circulatory responses to beta adrenergic blockade with alprenolol. Studies in patients with chronic heart disease. American Journal of Cardiology, 29, 26. 
Majid, P. A., Sharma, B., Saxton, C., Stoker, J. B., and Taylor, S. H. (1970). Haemodynamic effects of oxprenolol in hypertensive patients. Postgraduate Medical Journal, 46, November Supplement, p. 67.

McCredie, R. M. (1970). Haemodynamic effect of LB46. New Horizons in Medicine (1). Symposium on Beta Adrenergic Blocking Agents, Sydney, A ustralia, 1970, p. 79. Sandoz.

Sealey, B. J., Liljedal, J., Nyberg, G., and Ablad, B. (1971). Acute effects of oral alprenolol on exercise tolerance in patients with angina pectoris. A dose-response study. British Heart Journal, 33, 481.

Sowton, E. (1970). Angina Pectoris Symposium, Dipolissa, Finland 1970, edited by P. I. Halonen, A. Eisalo, and J. Perasalo, p. 162. Hassle. and Smithen, C. (1971). Double-blind three-dose trial of oral alprenolol in angina pectoris. British Heart Journal, 33, 601.

Taylor, S. H., Thudani, U., and Sharma, B. (1972). Comparison of the symptomatic, electrocardio- graphic and circulatory effects of propranolol, oxprenolol and practolol. New Perspectives in Beta Blockade. Proceedings of a Symposium Aarhus, Denmark, 1972, p. 177. Ciba.

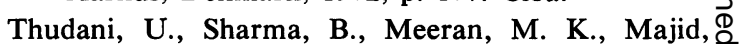
P. A., Whitaker, W., and Taylor, S. H. (1973). Comparison of adrenergic beta-receptor antag- $\backsim$ onists in angina pectoris. British Medical Journal, $\vec{\circ}$ $1,138$.

Turner, A. S. and Peel, J. S. (1970). Clinical and $\vec{\omega}$ haemodynamic studies with beta blockade. Symposium on beta adrenergic blocking agents. New Horizons in Medicine I, p. 51. Sandoz, Sydney, Australia.

Wilson, D. F., Watson, O. F., Peel, J. S., Langley, $\overrightarrow{0}$ R. B., and Turner, A. S. (1968). Some haemodynamic effects of Trasicor (Ciba 39, 089Ba). New Zealand Medical Journal, 68, 145.

Requests for reprints to: Dr. Edgar Sowton, The Cardiac Department, Guy's Hospital, London SE1. 